ROCZNIKI HUMANISTYCZNE

Tom LXVIII, zeszyt 7 - 2020

DOI: http://dx.doi.org/10.18290/rh20687-6

AGNIESZKA GOŁĘBIOWSKA-SUCHORSKA

\title{
OSTATNI PAPIEROS I TYTONIOWA WRÓŻBA, CZYLI KILKA UWAG O FOLKLORZE PALACZY
}

Ja to lubię palić w grupie - zawsze się pogada, nawet jak tam kogoś poczęstować trzeba.

(kobieta, ur. 1946)

Tytoniowi na przestrzeni wieków przypisywano wiele różnych właściwości - leczniczych, uspokajających, toksycznych, sakralnych (szerzej zob. np. Gately; Bogdanov). Widok człowieka palącego tytoń i w efekcie wypuszczającego dym przez dziurki w nosie i usta początkowo wywoływał u Europejczyków asocjacje demoniczne (Bogdanov 7). Taka pejoratywna ocena tytoniu dominowała także $\mathrm{w}$ tradycyjnym folklorze słowiańskim. W wątkach ajtiologicznych przypisywano mu negatywne, szatańskie pochodzenie. $\mathrm{Na}$ przykład według przekazu jednej z bajek polskich zapisanych w Galicji tytoń wyrósł z prochu złej córki kowala, która nie pomogła Jezusowi wędrującemu po ziemi. Dziewczyna splunęła z pogardą na Chrystusa, dlatego spluwanie towarzyszy paleniu tytoniu (Kowerska 68-69) ${ }^{1}$. Wiele wschodniosłowiańskich opowieści ajtiologicznych wskazuje na demoniczną genezę tej rośliny, która ma pochodzić z odchodów diabła, z prochu szatana zrzuconego z nieba, ze zwłok gwałciciela, grzesznicy spółkującej z psem lub Judasza. Niektóre wątki przypisują szatanowi stworzenie tytoniu (a potem także cygar, papierosów i sklepów je oferujących). Według jednej z opowieści czort jakoby chciał zmusić ludzi do opłakiwania jego zmarłej matki i wymyślił

Dr hab. Agnieszka GoŁęBiowska-Suchorska, prof. uczelni - Uniwersytet Kazimierza Wielkiego w Bydgoszczy, Wydział Literaturoznawstwa, Katedra Literatury Polskiej i Rosyjskiej; adres do korespondencji: ul. Jagiellońska 11,85-067 Bydgoszcz; e-mail: agnieszka@suchorscy.pl. ORCID: https://orcid.org/0000-0002-9397-9179.

Dr habil. AgNiESZKa GoŁĘBIOWSKA-SuChORSKA, prof. at UKW - Kazimierz Wielki University in Bydgoszcz, Faculty of Literature Sudies, Department of Polish and Russian Literature; address for correspondence: ul. Jagiellońska 11, 85-067 Bydgoszcz; e-mail: agnieszka@suchorscy.pl. ORCID: https://orcid.org/0000-0002-9397-9179.

${ }^{1}$ Bajka realizuje wątek T 753 „Kowal i Chrystus (odmłodzenie)” (według Krzyżanowski). 
tabakę, która wywołuje łzawienie. Bóg natomiast wymyślił fajki do palenia diabelskiego suszu, aby ludzie spluwali po jego spożyciu (Belova 148-150, 208-209). Niekiedy folklor tradycyjny wyśmiewał uzależnienie od nałogu, ponieważ nałóg wymagał nakładów finansowych (zob. Kowerska 67-68). Ocena tytoniu w folklorze tradycyjnym nie była jednak jednoznacznie negatywna. Na przykład w jednej z ukraińskich legend ajtiologicznych Matka Boska pobłogosławiła tytoń, ponieważ zapach tabaki uwolnił ją od bólu głowy (Belova 209). Z kolei w polskiej bajce chłop został na spowiedzi ukarany przez księdza nie za palenie „diabelskiego ziela”, ale za to, że wciąż palił cudzy tytoń i nie dziękował za niego („O chłopie...” 402-403)2. O ile w folklorze tradycyjnym negatywny stosunek do tytoniu i jego konsumpcji był związany przede wszystkim z przypisywaną tej roślinie proweniencją demoniczną, to w folklorze współczesnych palaczy wynika on głównie ze szkodliwych konsekwencji zdrowotnych palenia. Negatywne konotacje wywołuje świadomość realnych zagrożeń wynikających z konsumpcji wyrobów tytoniowych. Kampanie społeczne nieustannie przypominają o szkodliwości palenia, a na paczkach papierosów umieszczane są informacje o zagrożeniu chorobami. Drastycznym posunięciem było wprowadzenie w Polsce od 2016 r. paczek papierosów, tytoniu z tekstowym ostrzeżeniem o szkodliwości palenia wzbogaconym ostrzeżeniem graficznym, czyli zdjęciami narządów zaatakowanych chorobą nowotworową. Akt palenia tytoniu wywołuje więc również współcześnie negatywne asocjacje, choć bez konotacji demonicznych. Dla palaczy jednak ten akt, jak wynika z przeprowadzonych przeze mnie rozmów, jest przede wszystkim źródłem doznań pozytywnych - dostarcza konkretne odczucia fizyczne, rozluźnia lub pozwala się skupić, bywa ukoronowaniem lub uzupełnieniem innych przyjemności (seks, dobry posiłek, kawa), „zabija samotność” (wywiad, kobieta, ur. 1958), pomaga w nawiązaniu rozmowy. Postawa palaczy wobec palenia charakteryzuje się więc jednoczesnym występowaniem pozytywnego i negatywnego nastawienia, co jest konsekwencją narzuconej z zewnątrz świadomości szkodliwości palenia i wewnętrznego pragnienia jego doświadczania. Konwersacje z osobami palącymi w kontaktach prywatnych i przypadkowych stały się bodźcem do sformułowania dwóch hipotez badawczych: pierwsza zakładała istnienie odrębnego folkloru palaczy, druga natomiast, że jedną z funkcji owego folkloru jest łagodzenie ambiwalencji postaw palaczy wobec palenia. W celu zweryfikowania obu hipotez przeprowadzono badania terenowe metodami wywiadu, rozmowy oraz ankiety bezpośredniej i elektronicznej.

\footnotetext{
${ }^{2}$ Bajka realizuje wątek legendowy T 789 „Pokuta za tytoń” (według Krzyżanowski).
} 
Materiał badawczy dla niniejszej analizy został zebrany w latach 20172019 w Bydgoszczy i okolicznych miastach ${ }^{3}$. Wywiady przeprowadzono z 62 osobami, ankiety wypełniło 106 badanych, 18 wypowiedzi zgromadziłam w wyniku spontanicznych rozmów z przypadkowo spotkanymi osobami. Łącznie badaniem zostało objętych 209 respondentów, spośród których 23 osoby nie potrafiły podać żadnych informacji cennych dla badacza, skupiały się na własnych zmaganiach z nałogiem, wspomnieniach, które - choć niekiedy ciekawe - nie dostarczyły danych odnośnie do interesujących mnie zagadnień i gatunków folkloru. Ostatecznie więc źródłem materiału badawczego okazały się wypowiedzi 186 osób, spośród których wyodrębniłam dwie grupy wiekowe - 127 osób to studenci i uczniowie (pełnoletni), urodzeni w latach 1980-2000; 59 osób to przedstawiciele różnych zawodów urodzeni w latach 1946-1975. Respondentami były osoby aktualnie lub w przeszłości palące tytoń (115 osób z młodszej grupy i 58 ze starszej) lub korzystające z tzw. papierosów elektronicznych, czyli elektronicznych inhalatorów nikotyny (12 osób z młodszej grupy, 1 ze starszej).

W swoich rozważaniach opierałam się na szerokiej antropologicznej definicji folkloru, sformułowanej przez Piotra Kowalskiego, według którego

(...) folklor to zbiór tekstów-zachowań (pojmowanych semiotycznie), które zawierają w sobie manifestacje mechanizmów (tzn. sposobów i konkretnych rozwiązań) zaspokajania podstawowych potrzeb psychospołecznych jednostki. $($ Kowalski, 131)

Takie zdefiniowanie folkloru pozwala wyodrębnić folklor palaczy jako folklor nastawiony na zaspokojenie określonych „potrzeb psychospołecznych” konkretnej ,jednostki”, czyli palacza tytoniu. Według Piotra Bogatyriewa i Romana Jakobsona istnieją grupy zróżnicowane np. wiekiem, płcią czy zawodem, które ,produkują folklor dla siebie samych” (Bogatyriew i Jakobson 180). Taką właśnie grupą są palacze - operują „gatunkami, zrozumiałymi i ważnymi tylko dla nich". Środowisko palaczy jest bardzo zróżnicowane, ponieważ nałogowi ulegają przedstawiciele obu płci, w różnym wieku, o różnym statusie społecznym, wykształceniu, światopoglądzie. Stąd folklor pa-

\footnotetext{
${ }^{3}$ Za pomoc w gromadzeniu materiału dziękuję mgr Justynie Joppek oraz Oldze Suchorskiej.

${ }^{4}$ Stosunkowo szerokie rozumienie terminu postulował już Julian Krzyżanowski: „Materiał nazywany folklorem obejmuje zjawiska z dziedziny ustalonych zwyczajów ogólnych, powszechnych, niejednostkowych, zwłaszcza zwyczajów o charakterze obrzędowym; następnie zjawiska z dziedziny wierzeń demonologicznych, meteorologicznych, medycznych, zawodowych i wszelkich innych; wreszcie zjawiska z dziedziny kultury artystycznej, muzyczno-słownej, z grubsza odpowiadające pojęciu literatury ustnej” (Stownik folkloru polskiego 106).
} 
laczy należałoby także określić za Michałem Walińskim jako „interspołeczny", czyli jako formy twórczości wspólne wielu środowiskom, grupom społecznym. Palacze tworzą swoistą subkulturę (por. Hernas 12), są - według terminologii Janusza Maciejewskiego - grupą zorganizowaną „na zasadzie wspólnej sytuacji, łączącej ludzi w środowisko na krótki czas, ale powtarzającej się w życiu" (Maciejewski 98). Uwarunkowanej nawykiem powtarzalności aktu palenia tytoniu towarzyszy powtarzalność zachowań, gestów oraz tekstów. Wynikające z przytoczonych definicji folkloru kryteria powtarzalności, wspólnoty sytuacji, przekazu w obrębie własnej grupy pozwalają definiować folklor palaczy jako folklor odrębnej subkultury.

W badaniu uzyskano materiał dotyczący wielu aspektów palenia tytoniu, m.in. związku aktu palenia ze sferą seksualną, sposobów wyłudzania/pożyczania papierosa, a zwłaszcza zasad savoir vivre'u, przy czym wiele opisanych działań miało znaczenie wieloaspektowe. Konwenans towarzyski wymaga na przykład, by nie dmuchać drugiej osobie w twarz, ponieważ oznacza to wykluczenie $\mathrm{z}$ grupy, negatywny stosunek, np.: ,w twarz dmucham, jak kimś gardzę” (ankieta, kobieta, ur. 2000), „dmuchanie dymem w twarz jest oznaką braku szacunku" (ankieta, mężczyzna, ur. 1998). Według niektórych badanych jednak dmuchanie dymem w twarz może być także interpretowane jako wyraz zainteresowania osobą płci przeciwnej - „że ma się «ochotę na niego»" (ankieta, kobieta, ur. 1989).

W kontekście interesującego mnie łagodzenia ambiwalencji oceny palenia zakres tematyczny prezentowanych w niniejszym artykule wyników badania zawężono do znajomości przez respondentów powiedzeń, zakazów, dowcipów, utartych form językowych, zachowań przesądnych, działań symbolicznych odnośnie do trzech grup tematycznych:

- papierosów elektronicznych

- choroby nowotworowej,

- przesądów oraz przepowiedni.

W trakcie wywiadów respondentom wyjaśniano, co jest przedmiotem zainteresowania badacza, nie podawano jednak konkretnych przykładów z zakresu folkloru palaczy ani odpowiedzi do wyboru.

\section{PAPIEROS ELEKTRONICZNY}

Pojawienie się papierosów elektronicznych (e-papierosów) miało być zdrowszą alternatywą dla palenia tradycyjnego, choć opinie medyczne w tej sprawie nie są jeszcze jednoznaczne. Temat papierosów elektronicznych wy- 
stąpił w wypowiedziach niewielu respondentów ${ }^{5}$. Sami użytkownicy inhalatorów nikotyny nie podali żadnych powiedzeń, żartów, zakazów itp. na temat e-papierosów. Znamienne, że chcąc pomóc mi w badaniu, zwolennicy papierosów tradycyjnych proponowali, abym zasięgnęła informacji o dowcipach na temat papierosów elektronicznych w Internecie (3 osoby ze starszej grupy i 4 z młodszej, wywiady). Wypowiedzi palaczy tradycyjnych o e-palaczach były najczęściej ironizująco-dowcipne. Na przykład jeden z badanych nazwał kpiąco użytkowników inhalatorów tytoniu ,palaczami długopisów” (rozmowa, mężczyzna, ok. 50 lat), inny stwierdził, że „plastikowe rurki palą” (rozmowa, mężczyzna, ok. 65 lat). Z kolei młoda zwolenniczka tytoniu w bibułce wyraziła opinię, że e-palacze ,pewnie chcą być fit, ale jakby palili normalne, to by i tak byli szczupli" (rozmowa, kobieta, ok. 20 lat). W wypowiedziach pięciu zwolenników tradycyjnych papierosów ich elektroniczne zamienniki pojawiły się w kontekście funkcji społecznej aktu palenia. Rozmówcy wskazywali np., że „elektroniczne to można bez towarzystwa palić” (ankieta, kobieta, ur. 1949); „jakby wszyscy mieli te «e» palić, to by się nie widzieli, takie chmury by były” (wywiad, mężczyzna, ur. 1969). Rozmówcy przyznawali jednocześnie, że także tradycyjne papierosy palone są często w samotności - w samochodzie, na przystankach, w parku czy we własnym mieszkaniu. Ważna okazała się możliwość dzielenia się zwykłym papierosem, elektroniczny substytut nie daje takiej możliwości - jak z powątpiewaniem zauważyła jedna z respondentek: „,z paczki to poczęstujesz, a z tego urządzenia to przecież nie można chyba?" (wywiad, kobieta, ur. 1950). Jak wynikało $\mathrm{z}$ wielu wypowiedzi na temat papierosów tradycyjnych, palacze cenią sobie możliwość współdzielenia papierosa i przywiązują wagę do stosowania określonych zasad, np. „otwierając paczkę przy grupie, należy (ale nie trzeba) poczęstować osoby palące, to jest «złote rozdanie»" (ankieta, mężczyzna, ur. 1997).

Wypowiedzi respondentów dotyczące dzielenia się papierosami zwracają uwagę na fakt, że wspólny akt palenia tytoniu jednoczy często przedstawicieli bardzo różnych grup społecznych, tworzą oni swoistą wspólnotę „nałogowych doświadczeń”. Społeczna funkcja palenia, wywołana w wypowiedziach respondentów tematem e-papierosów, związana jest, jak można przypuszczać, między innymi z łagodzeniem ambiwalencji w folklorze palaczy. Palenie to swoista aktywność społeczna, łącząca ludzi świadomie i zgodnie z prawem zażywających substancji, których szkodliwość została udowodniona i jest powszechnie znana. Wspólne palenie to nie tylko satys-

\footnotetext{
${ }^{5}$ Według statystyk do używania papierosów elektronicznych przyznaje się zaledwie $2 \%$ ogółu Polaków (zob. np. Kantar Public 33).
} 
fakcja z kontaktów międzyludzkich, ale także, zapewne podświadome, dzielenie $\mathrm{z}$ innymi osobami obaw, które wyraźniej uwidaczniają się w werbalnych i akcjonalnych aktywnościach palaczy, które omówię poniżej.

\section{ŚMIERĆ I CHOROBA NOWOTWOROWA}

Zaledwie jeden z rozmówców, zwolennik papierosów tradycyjnych, w kontekście rozmowy o zagrożeniu chorobą nowotworową wypowiedział się o szkodliwości e-papierosów. Nie była to jednak relacja wspomnieniowa czy biograficzna, ale nawiązanie do informacji pojawiających w mediach:

A czytała Pani o tych elektronicznych, co tak wybuchają nagle? Mi kiedyś wnusia taki filmik pokazała. I co tu bardziej szkodliwe? Ja od zwykłego peta to raczej nie wybuchnę. (rozmowa, mężczyzna, ok. 65 lat) ${ }^{6}$

Tylko jeden przesąd wskazany przez respondentów miał bezpośredni związek ze śmiercią, choć takiej, która nie jest wynikiem choroby nowotworowej, stanowiącej podstawowe zagrożenie dla palaczy. Według rozmówców śmiercią marynarza na morzu skutkować ma każde zapalenie papierosa od świeczki, stąd zakaz stosowania takiego sposobu. Przesąd ten znało 32 badanych ze starszej grupy i $24 \mathrm{z}$ młodszej, ale nikt nie potrafił wyjaśnić jego pochodzenia czy związku świeczki i papierosów z marynarzami. Trzech badanych z młodszej grupy odesłało mnie do Internetu jako potencjalnego źródła informacji na ten temat ${ }^{7}$. Niezależnie od nieznajomości genezy przesądu wszyscy potwierdzali, że nie tylko znają, ale i praktykują ten zakaz, tzn. rzeczywiście nie odpalają papierosa od świeczki. Takie bezrefleksyjne stosowanie się do zakazów przywodzi na myśl stwierdzenie Edwarda Sapira, że „działamy tym pewniej, im bardziej nieświadomi jesteśmy wzorów, które nami kierują" (Sapir 154). Potwierdza także słuszność stwierdzenia Piotra Kowalskiego, że folklor to zbiór „zachowań-tekstów”, które „stanowią wspólne, «oczywiste» dobro przekazywane w bezpośrednich kontaktach” (Kowalski 131).

\footnotetext{
${ }^{6} \mathrm{~W}$ Internecie rzeczywiście są powielane relacje o samoistnie wybuchających papierosach elektronicznych (zob. np. „E-papieros wybuchł 11 września”, „E-papieros wybuchł. Palacz z poparzeniami drugiego stopnia” (wideo); „To nie fajerwerki w kieszeni...”; „Wybuchające e-papierosy to nie żart").

${ }^{7}$ Podobno w trakcie rejsu między portami w wolnych chwilach marynarze zajmowali się wytwarzaniem zapałek, które po przybyciu do portu sprzedawali, co stanowiło dla nich dodatkowy dochód. Odpalanie od świeczki zmniejszało zapotrzebowanie na zapałki i zarobek marynarzy (zob. np. „Przesądy marynarskie”).
} 
Jak zauważył Michał Waliński, dla właścicieli i użytkowników folkloru nie jest ważne pochodzenie jego składników, ale ich użyteczność, funkcja (Waliński 21). Respondenci nie potrafili określić, jaką funkcję zakaz zapalania papierosa od świeczki pełni współcześnie, kiedy - jak niektórzy wskazywali - w ogóle rzadko używa się świeczek, ponieważ są do dyspozycji elektryczność, zapałki i zapalniczki. Zapewne, jak każdy zakaz, tak i ten definiuje zachowania prawidłowe, których nieprzestrzeganie określa status osoby w grupie - nieznajomość swoistego savoir vivre'u degraduje.

Choroba nowotworowa pojawiała się dość często w wypowiedziach badanych jako swoisty towarzysz aktu palenia. Na 186 badanych 54 osoby wskazały jakąś formę słowną, w której pojawiał się leksemem „rak” jako potoczne określenie nowotworu. Zastępcze określenia aktu palenia stanowiące warianty powiedzenia „karmić raka” (,idę nakarmić raka”, „trzeba dokarmiać raka”, „pora nakarmić raka”) znało 28 badanych ze starszej grupy oraz $15 \mathrm{z}$ młodszej. Trzy osoby z młodszej grupy znały to powiedzenie od rodziców lub dziadków, choć deklarowały, że nie stosują go osobiście. Zwrot „idę nakarmić raka”, który zastępuje zwykłe informacyjne stwierdzenie „idę na papierosa", jest przeciwieństwem eufemizmu, dosadnie i wprost nazywa zagrożenie. Wynika z niego, że „rak” niejako stawia wymagania, oczekuje palacza, potrzebuje pokarmu. Ta animizacja choroby jest metaforą nałogu, owej chronicznej potrzeby dostarczania szkodliwych substancji do organizmu człowieka.

Stosunek palaczy do choroby nowotworowej przejawia się także w zwyczaju stukania w dno paczki papierosów, interpretowanym jako sposób „obudzenia raka”. Wskazało go 14 osób ze starszej grupy badanych oraz $8 \mathrm{z}$ młodszej. Na przykład mężczyzna zapytany przeze mnie na przystanku autobusowym, po co stuka w paczkę, odpowiedział, że „trzeba najpierw raka obudzić”, i uzasadnił to powiedzenie parafrazując inne („wbić ostatni gwóźdź do trumny”): „A tak się jakoś mówi, bo to przecież kolejny «papieros do trumny»" [śmiech] (mężczyzna, ok. 65-70 lat). Stukanie w dno paczki jest formą prowokacji nowotworu. W przytoczonych powiedzeniach o karmieniu i budzeniu „raka” choroba jest nazywana jakby „po imieniu”, a nie jak oficjalna jednostka choroba. Używając tego „imienia”, palacz stwarza wrażenie pewnej komitywy z chorobą, podkreśla, że jest świadomy szkodliwości palenia, sam przecież „budzi raka” - i mimo to pali. Humor, a właściwie w tym przypadku czarny humor, jest pewnego rodzaju transformacją obrazu świata i manifestacją jego odbioru. U jego podstaw leży poczucie czy świadomość zagrożenia, humorystyczne zachowanie słowne 
nie prowadzi jednak do rozwiązania problemu, proponuje jedynie emocjonalny stosunek do niego. Jest więc psychicznym antidotum na to, co chyba jednak przeraża. Lęk przed zdrowotnymi konsekwencjami palenia zastępowany jest dzięki takim powiedzeniom przekorną postawą pewności siebie wobec zagrożeń, co stanowi swoisty mechanizm obronny.

Choroba nowotworowa pojawiła się również w dowcipach, które przytoczyło 37 osób z grupy młodszej i 15 ze starszej. Były to właściwie warianty jednego dowcipu sytuacyjnego o niezmiennej strukturze, zestawie chorób i puencie. W wersji jednego z respondentów brzmiał on następująco:

Facet w kiosku chce kupić paczkę fajek. No i sprzedawca daje mu pierwszą paczkę z brzegu, a tam napis: „Palenie tytoniu to przyczyna problemów z erekcją". Facet tak wziął tę paczkę..., przeczytał, obejrzał, ale nie płaci... No a potem ją oddaje i mówi: - To ja jednak poproszę te $\mathrm{z}$ rakiem... Są pewne priorytety, nie? [śmiech, mrugnięcie okiem] (wywiad, mężczyzna, 48 lat)

Wszystkie dowcipy przytoczone przez badanych wykorzystywały wątek wyboru mniejszego zła - najstraszniejszym zagrożeniem dla klienta były zaburzenia erekcji, a dowcipne zakończenie stanowił zawsze wybór choroby nowotworowej. Dowcipy te wskazują na świadomość zagrożenia i determinację palaczy - klienta nie dziwi hasło ostrzegawcze czy ilustracja stanu chorobowego na paczce papierosów, jest świadomy, że kupując tę paczkę, kupuje źródło choroby, ale decyzji o zakupie nie zmienia. Folklor zawsze był i nadal jest bardzo czułym „,barometrem zmian i stanów społecznych, kulturalnych" (Waliński 21), dlatego pojawienie się paczek ze słownym i graficznym ostrzeżeniem stało się sytuacją produktywną dla dowcipów jako przejawów aktywności folklorystycznej.

Teksty humorystyczne, nazywające nowotwór po imieniu lub wskazujące na możliwość wyboru konkretnego wariantu choroby, to przejaw swoistej przekory, postawa na przekór tym, którzy straszą nowotworem, a może i na przekór samej chorobie. Etiologa humorystycznych powiedzeń, dowcipów o „raku” wydaje się dość oczywista - wieloletnia kampania antytytoniowa, nacisk zewnętrzy (słowny, wizualny) prowadzą do wykształcenia pewnych mechanizmów obronnych, do których psychologia zalicza m.in. humor (za: Marchwicki 498). Zarówno jednak w powiedzeniach o „raku”, jak i w dowcipach o wyborze nowotworu wyczuwalny jest pewien fatalizm - wiara w przeznaczenie, tzn. w nieuchronność przyszłości, która przyniesie jakąś chorobę lub nawet śmierć jako konsekwencję palenia tytoniu. Dowcipy o „raku”, powiedzenia o nim jako towarzyszu aktu palenia (obudzić, nakar- 
mić) są manifestacją postawy wyznania i wyzwania. Wyznania - ponieważ ujawniają lęki palaczy, którzy nie mogą jednak pozostać obojętni wobec świadomości zagrożenia, a wyzwania - ponieważ humorystyczne potraktowanie zagrożenia jest próbą jego pokonania. Być może jest też próbą odparcia ewentualnych nacisków niepalących przez uprzedzenie ich ostrzeżeń, zamanifestowanie świadomości niebezpieczeństwa i świadomości wyboru dokonanego przez palacza.

\section{SZCZĘŚCIE I PROFETYZM}

Wypowiedzi wielu respondentów wskazywały na istnienie przekonania, że papieros może przynieść palaczowi szczęście lub nieszczęście, może także być interpretowany jako omen. W przeświadczeniu, że tytoń w bibułce może być źródłem przyszłego szczęścia, przejawia się wspomniana już przekora wobec zagrożenia chorobą lub śmiercią. W wypowiedziach 25 badanych ze starszej grupy i 32 badanych $\mathrm{z}$ młodszej pojawiał się przesąd, zgodnie $\mathrm{z}$ którym pierwszy papieros $\mathrm{w}$ paczce należy odwrócić do góry nogami i zostawić go na koniec, żeby wypalić „na szczęście”. Nazywany jest „szczęściarzem” (ankieta, kobieta, ur. 1989), „szczęśliwką” (wywiad, kobieta, ur. 1998) ${ }^{8}$, a odpalając go „można pomyśleć życzenie” (ankieta, kobieta, ur. 1998). Skorelowany z tym przesądem jest zwyczaj stanowiący, że ostatniego papierosa z cudzej paczki nigdy się nie bierze, bo to nie tylko ostatni, ale przede wszystkim „szczęśliwy”. Jak stwierdził jeden z respondentów, „ostatniego trzeba bronić” (wywiad, mężczyzna, ur. 1956). O wadze tego zakazu świadczą powiedzenia, w których wobec konsumenta ostatniego cudzego papierosa wyrażana jest pogarda. W 23 wypowiedziach respondentów pojawiło się w różnych wariantach powiedzenie, zgodnie z którym tylko kobieta lekkich obyczajów ma czelność odebrać właścicielowi ostatniego papierosa, na przykład: „ostatniego to kurwa bierze” (ankieta, mężczyzna, ur. 1991), „ostatniego to tylko kurwa weźmie” (wywiad, kobieta, ur. 1975). To przeświadczenie o pierwszym papierosie jako szczęśliwym wpisuje się w tradycje folkloru, dla którego charakterystyczne było przypisywanie szczególnego znaczenia początkowi i końcowi w kategoriach temporalnych, porządkowych, przestrzennych, zarówno w obrzędowości dorocznej i rodzin-

\footnotetext{
${ }^{8}$ Nikt z badanych nie odniósł się do krążącej w Internecie etymologii „szczęściarza” jako szczęśliwego strzału - papierosa z marihuaną w Lucky Strike (zob. np. „Czy papierosy Lucky Strike").
} 
nej, jak i w obrzędach hodowlanych czy budowlanych (zob. Valentsova, Marina i Sedakova 674-679).

Przekonanie, że wśród wszystkich (szkodliwych) papierosów w paczce zawsze jest ten jeden, który zapewnia palaczowi szczęście, nadaje wartość pozytywną aktowi palenia, być może równoważąc poczucie zagrożenia. Kojarzenie niezdrowego aktu palenia tytoniu z zabezpieczeniem palaczowi przychylności losu przywodzi na myśl znaną w psychologii strategię obronną, jaką jest idealizacja, czyli wyolbrzymione przypisywanie cech pozytywnych (za: Marchwicki 498).

W wypowiedziach respondentów pojawiły się także racjonalne uzasadnienia nieczęstowania się ostatnim papierosem, na przykład: „Ja zawsze się zastanawiam, czy komuś później nie zabraknie. Na zakładzie mówią: «Papieros i kawa to codzienna podstawa»” (mężczyzna, ur. 1981); „żeby miał tego ostatniego dla siebie" (kobieta, ur. 1992). Dla autorów przytoczonych wypowiedzi motywacją zakazu konsumpcji ostatniego cudzego papierosa jest empatia, co potwierdza wcześniejsze stwierdzenie, że palaczy łączy wspólnota doświadczeń.

Odrębną grupę zachowań wskazywanych przez respondentów stanowią reakcje w sytuacjach, które mają grozić nieszczęściem. Niepowodzeniem mogą skutkować różne „nieprawidłowe” zachowania. Na przykład nie należy odmawiać komuś papierosa w ważnym dniu (m.in. egzaminu, sprawy w sądzie -4 badanych): „Trzeba poczęstować, bo odmowa to może przynieść nieszczęście" (wywiad, kobieta, ur. w latach 90.). Zakaz ten przywodzi na myśl znane $\mathrm{w}$ folklorze tradycyjnym przekonanie, że odmówienie czegoś osobie w fazie progowej (liminalnej w modelu obrzędów przejścia van Gennepa), np. kobiecie brzemiennej, pociąga za sobą negatywne konsekwencje (zob. szerzej np. Tolstaya 160-164). Częstowanie się papierosem zaproponowanym przez kobietę także ma zwiastować nieszczęście (3 respondentów): „Od kobiety się papierosów nie bierze, bo przyniesie to pecha, ale teraz to już się czasy zmieniły, jak nie ma pieniędzy, to na pecha nie patrzysz, tylko palisz" (wywiad, kobieta, ur. 1955). Pięciu respondentom znany był także zakaz zapalania więcej niż dwóch papierosów od jednej zapałki, bo wróży to nieszczęście: „odpalisz trzeciemu i będzie pech” (wywiad, mężczyzna, ur. 1990), „nigdy nie zapalamy zapałką więcej niż dwóch papierosów, bo wróży to nieszczęście" (ankieta, kobieta, ur. 1994). Tylko jeden respondent ze starszej grupy podjął próbę uzasadnienia tego zakazu: 
To dziadek mój mówił, że trzech papierosów jedną zapałką się nie pali. Coś tak chodziło o wojnę, no ja nie wiem..., ale gdzie tam trzy papierosy, człowiek by sobie palce tylko poparzył. (wywiad, mężczyzna, ur. 1946)

Z wypowiedzi sześciu badanych wynikało, że trójkrotność jest ważna także przy dzieleniu się papierosem, np.:

Kiedy pali się jednego na pół, właściciel papierosa powinien zaciągnąć się pierwszy, a każdy z palących powinien wykonać trzy zaciągnięcia i przekazać papierosa. (ankieta, kobieta, ur. 1970)

(...) zapalić tego papierosa na pół - 3 buchy jedna osoba, potem 3 buchy druga osoba i tak do końca papierosa. Żeby wszystko było w porządku. (rozmowa, kobieta, ok. 25-30 lat)

To przypisywanie trójce szczególnego znaczenia także ma swoją genezę w folklorze tradycyjnym, dla którego cykl trójfazowy jest cyklem wzorowym, ponieważ m.in. wpisuje się w niego rytm życia człowieka, trójka jest zasadą budowy świata i wiąże się ze sferą sacrum (zob. Wójtowicz).

Szczególnie intrygujące $\mathrm{w}$ wypowiedziach respondentów było przypisywanie papierosom funkcji profetycznej. $Z$ wypowiedzi badanych wynika, że przypadkowy upadek papierosa interpretowany jest jako zdarzenie, które ma głębszy sens, jest rodzajem komunikatu - zapowiada przyszłe negatywne zdarzenia. Konsekwencji upadku papierosa na ziemię można, według badanych, uniknąć, stosując się do kilku różnych zasad:

Jak spadnie papieros na ziemię, to trzeba go podnieść szybko i pierwszego macha powinna wziąć osoba, która jest właścicielem papierosa, to tak na szczęście. (wywiad, mężczyzna, ur. 1975)

(...) nie można go od razu spalić, należy włożyć z powrotem do paczki i zapalić jako ostatniego. Symbolizuje to nieszczęście i może przynieść jakieś złe nowiny. Najlepiej też, żeby podniosła go osoba druga, która jest z nami w towarzystwie. (rozmowa, kobieta, ur. w latach 90.)

Jeśli podniesie go palacz, to ktoś powinien go uderzyć (żeby nie spotkało palacza jakieś nieszczęście). (ankieta, kobieta, ur. 1991)

Z kolei jako pozytywny znak interpretowane jest zapalenie się papierosa „nieprawidłowo”, tzn. częściowo lub krzywo. Wspomniało o tym zaledwie 6 badanych na 186, jednak, ponieważ przepowiednie były zawsze pozytywne, przypisywanie papierosom funkcji omenu stanowi strategię nadawania pozytywnych wartości działaniu grożącemu negatywnymi konsekwen- 
cjami. Jeden rozmówca ze starszej grupy wspominał, że jeśli przy zapalaniu papieros zajął się ogniem w połowie, to „w wojsku mówili, że luba kocha i tęskni" (wywiad, mężczyzna, ur. 1962). Pięć respondentek z młodszej grupy także wskazało ten przesąd - odpalony krzywo papieros znaczy, że „ktoś myśli o odpalającej osobie” (ankieta, kobieta, ur. 1985), papieros odpalony w części zwiastuje, że „komuś przyszedł na myśl ten, co zapala papierosa” (rozmowa, kobieta, ok. 30 lat), „ktoś myśli o Tobie” (ankieta, kobieta, ur. 1989).

Przytoczone wypowiedzi respondentów o szczęściu i nieszczęściu jako konsekwencjach obchodzenia się z papierosami (pierwszy-ostatni, podniesiony, odmówiony, odpalony jako trzeci) oraz przekonanie o papierosie-omenie przypisują tytoniowi w bibułce swoistą moc sprawczą. Ze znanych badanym przekonań przesądnych wynika, że papieros wpływa lub może wpływać (dzięki stosowaniu określonych zasad) na los palacza wyłącznie pozytywnie. Być może takie przekonania równoważą obawy palaczy dotyczące negatywnego wpływu palenia na ich życie i zdrowie.

Z materiału zebranego od współczesnych palaczy udało się wyodrębnić tylko trzy gatunki folkloru słownego reprezentowane przez pojedyncze przykłady - wyrażenia o karmieniu i budzeniu „raka”, dowcip o wyborze między zaburzeniami erekcji i chorobą nowotworową oraz powiedzenie o prostytutce częstującej się ostatnim papierosem. Odnotowano natomiast więcej zachowań przesądnych dotyczących częstowania papierosem (ostatni, odmówiony), upadku czy zapalania papierosa. Jak każdy przejaw folkloru, również werbalne i akcjonalne przykłady folkloru palaczy charakteryzuje konwencjonalność, formuliczność, dzięki czemu łatwo stają się własnością grupy. Wszystkie zarejestrowane w badaniu przejawy folkloru palaczy tworzą kanwę dla funkcjonowania zbiorowego, tworzą specyficzną kulturę grupy, która jest bardzo zróżnicowana. Pewne zachowania są powtarzalne, co wynika z faktu, że są wynikiem wspólnych doświadczeń - każdemu palaczowi kończą się papierosy i ten ostatni staje się niekiedy szczególnie cenny, czasem papieros odpala się nierówno, każdy palacz styka się z kampanią antynikotynową (społeczną lub rodzinną). Powtarzalność czynności palenia papierosów generuje zachowania, które, być może, zapewniają jednostce poczucie bezpieczeństwa gwarantowane powtarzalnością reguł i pozwalają na oczekiwanie zachowań przewidzianych w danej sytuacji. Można więc zaryzykować stwierdzenie, że wśród palaczy znane są swoiste wzory kulturowe, 
czyli podpowiedzi, jak jednostka powinna reagować w różnych sytuacjach, aby były to zachowania zgodne z oczekiwaniami i niepowodujące konfliktu z innymi członkami grupy. Przeprowadzona analiza materiału badawczego potwierdziła więc hipotezę o istnieniu folkloru palaczy jako folkloru odrębnej subkultury.

$\mathrm{Na}$ gatunkach folkloru jako formach ekspresji życia zbiorowego wyciska piętno aktualny kontekst polityczny, kulturowy czy społeczny. Dlatego mimo zbieżności tematyki (palenie tytoniu) postawę tradycyjnego i współczesnego folkloru wobec aktu konsumpcji suszu $\mathrm{z}$ tej rośliny cechują różne motywacje, interpretacje i odmienność gatunkowa wypowiedzi. Zgodnie z definicją Michała Walińskiego folklor współczesnych palaczy należałoby określić jako „folklor bez dowodu tożsamości”, ponieważ nie jest on reliktem folkloru tradycyjnego (Waliński 27). Folklor tej grupy zawiera jednak także elementy świadczące o kontynuacji treści kulturowych - przypisywanie szczególnego znaczenia liczbie trzy, pierwszemu-ostatniemu papierosowi, strach przed konsekwencjami odmowy poczęstowania. Folklor palaczy sytuuje się ponad wszelkimi podziałami i wykorzystuje charakterystyczne formy komunikacji realizujące wspólne im tematy i odzwierciedlające podobny system wartości. Dzięki temu folklor ten daje gwarancję porozumienia.

Zgromadzony materiał dostarczył także przykładów potwierdzających hipotezę, że jedną z funkcji folkloru palaczy jest łagodzenie ambiwalencji ocen palenia tytoniu. Konsekwencją świadomości zagrożeń, jakie niesie z sobą konsumpcja wyrobów tytoniowych, są stosowane w folklorze palaczy strategie obronne oparte na przekorze, humorze i idealizacji. Takie zastępowanie własnych negatywnych myśli lub uczuć, których człowiek unika (świadomość szkodliwości, strach przed konsekwencjami palenia), myślami, uczuciami lub zachowaniami pozytywnymi (zapewnianie szczęścia, przewidywanie szczęśliwej przyszłości), określanie jest w psychologii jako reakcja upozorowana (za: Marchwicki 496).

Omówione w niniejszym artykule badania nie miały na celu wyczerpującej analizy folkloru współczesnych palaczy, a jedynie uchwycenie jego niektórych przejawów i aspektów. Zaprezentowany przeze mnie materiał empiryczny jest, zgodnie z zamierzeniem, wybiórczy i ilustruje jedynie część istotnych wymiarów omawianego zjawiska, wskazuje jednak na możliwość rozszerzenia pola badawczego folkloru palaczy (np. status kobiety, seksualność, sposoby wyłudzania papierosa). 


\section{BIBLIOGRAFIA}

\section{ŹRÓDŁA}

„Czy papierosy Lucky Strike mają jednego tzw 'Szczęśliwca'?”. Onet, zapytaj.onet.pl/Category/ 001,002/2, 23839566, Czy_papierosy_Lucky_Strike_maja_jednego_tzw_quot Szczesliwca quot.html. Dostęp 02.09.2019.

„E-papieros wybuchł 11 września. 'To było jak zamach””. Radio Zet, archiwum.radiozet.pl/ Technologia-i-motoryzacja/E-papieros-eksplodowal-w-torebce-podczas-zakupow.Zobacz-WIDEO!-00028267. Dostęp 12.09.2019.

„E-papieros wybuchł. Palacz z poparzeniami drugiego stopnia (wideo)”. Kurier Poranny, poranny.pl/epapieros-wybuchl-palacz-z-poparzeniami-drugiego-stopnia-wideo/ar/9439656. Dostęp 11.09.2019.

Kowerska, Zofia. „Tabaka i tytuń u ludu wiejskiego”. Wisła. Miesięcznik geograficzny i etnograficzny, t. 14, z. 1, 1900, ss. 67-69.

„O chłopie, jak musiał pokutować za to, ze tutoń cudzy kurzał, a nie dziękował”. Jan Świętek. Lud nadrabski (od Gdowa po Bochnię). Nakładem Akademii Umiejętności, 1893.

„Przesądy Marynarskie”. Wykop.pl, www.wykop.pl/link/925911/przesady-marynarskie/. Dostęp 30.08.2019.

„To nie fajerwerki w kieszeni - to wybuchający e-papieros”. TECHNOLOGICZNA.PL, technologiczna.pl/ to-nie-fajerwerki-w-kieszeni-to-wybuchajacy-e-papieros/. Dostęp 15.09.2019.

„Wybuchające e-papierosy to nie żart. On nie miał szczęścia”. o2.pl, www.o2.pl/artykul/wybucha jaceepapierosy-to-nie-zart-on-nie-mial-szczescia-5965526756500097a. Dostęp 15.08.2019.

Белова, Олга, (сост.). «Народная Библия»: Восточнославянские этиологические легендь. «Индрик», 2004 [Belova, Ol'ga, (sost.). «Narodnaya Bibliya»: Vostochnoslavyanskiye etiologicheskiye legendy. Indrik, 2004].

\section{OPRACOWANIA}

Bogatyriew, Piotr, i Roman Jakobson. Folklor jako swoista forma twórczości. Przeł. Fryderyka Wayda i Piotr Bogatyriew, Semiotyka kultury ludowej, Państwowe Wydawnictwo Naukowe, 1975.

Gately, Ian. Kulturowa historia tytoniu. Przeł. Anna Kunicka. Aletheia, 2012.

Hernas, Czesław. „Miejsce badań nad folklorem literackim”. Pamiętnik Literacki, t. 66, z. 2, 1975, ss. 3-15.

Kantar Public (dla Głównego Inspektoratu Sanitarnego). Raport z ogólnopolskiego badania ankietowego na temat postaw wobec palenia tytoniu, gis.gov.pl/wp-content/uploads/2018/04/ Postawy-Polak\%C3\%B3w-do-palenia-tytoniu-Raport-2017.pdf, 2017. Dostęp 01.09.2019.

Kowalski, Piotr. Wspótczesny folklor i folklorystyka. O przedmiocie poznania $w$ dzisiejszych badaniach folklorystycznych. Polskie Towarzystwo Ludoznawcze, 1990.

Krzyżanowski, Julian. Polska bajka ludowa w uktadzie systematycznym, t. 1-2. Ossolineum. Wydawnictwo PAN, 1962-1963.

Maciejewski, Janusz. „Obszary trzecie” kultury. Teksty, nr 4, 1975.

Marchwicki, Piotr. „Mechanizmy obronne w ujęciu psychodynamicznym”. Seminare. Poszukiwania naukowe, vol. 21, 2005, ss. 491-507.

Sapir, Edward. Kultura, język, osobowość. Państwowe Wydawnictwo Naukowe, 1978. 
Stownik folkloru polskiego, red. Julian Krzyżanowski, Wiedza Powszechna, 1965.

Waliński, Michał. „Współczesna rzeczywistość folkloru. Glosa do dyskusji”. Literatura Ludowa, nr 1-3, 1979, ss. 19-32.

Wójtowicz, Magdalena. „Symbolika wybranych liczb - trójka”. Etnografia Lubelszczyzny - ludowe wierzenia o liczbach, http://teatrnn.pl/leksykon/artykuly/etnografia-lubelszczyzny-ludowewierzenia-o-liczbach/\#symbolika-wybranych-liczb-trojka. Dostęp 20.09.2019.

Богданов, Игорь. Дым отечества, или Краткая история табакокурения. Новое литературное обозрение, 2007 [Bogdanov, Igor'. Dym otechestva ili Kratkaya istoriya tabakokureniya. Novoye literaturnoye obozreniye, 2007].

Валенцова, Марина, и Ирина Седакова. „Первый-последний”. Славянские древности: Этнолинвистический словарь, т. 3. Ред. Н.И. Толстой, Международные отношения, 2004 [Valentsova, Marina, i Irina Sedakova. „Pervyy-posledniy”. Slavyanskiye drevnosti: Etnolingvisticheskiy slovar', t. 3. Red. N. I. Tolstoy, Mezhdunarodnyye otnosheniya, 2004].

Толстая, Светлана. „Беременность”. Славянские древности: Этнолинвистический словарь, т. 1, ред. Н.И. Толстой, Международные отношения, 1995 [Tolstaya, Svetlana. „Beremennost'”. Slavyanskiye drevnosti: Etnolingvisticheskiy slovar', t. 1, red. N.I. Tolstoy, Mezhdunarodnyye otnosheniya, 1995].

\section{OSTATNI PAPIEROS I TYTONIOWA WRÓŻBA, CZYLI KILKA UWAG O FOLKLORZE PALACZY}

\section{Streszczenie}

Celem artykułu jest przedstawienie wyników badań nad stosunkiem do palenia tytoniu odzwierciedlonym w folklorze współczesnych palaczy. Materiał badawczy stanowiły dane zebrane metodą wywiadu w latach 2017-2019 w Bydgoszczy i okolicznych miastach.

Zakres tematyczny wyników prezentowanych w niniejszym artykule zawężono do znajomości przez osoby palące (aktualnie lub w przeszłości) małych form słownych (powiedzenia, zakazy, dowcipy) odnoszących do choroby nowotworowej, przesądów, przepowiedni oraz papierosów elektronicznych. Wyodrębniono strategie obronne palaczy wobec zagrożeń chorobą nowotworową, m.in. humor, przekora, idealizacja.

Słowa kluczowe: folklor palaczy; zakazy; dowcipy; strategie obronne.

\section{LAST CIGARETTE AND TOBACCO FORTUNE TELLING, OR A FEW COMMENTS ABOUT THE SMOKERS' FOLKLORE}

$$
\text { Su m mary }
$$

This article aims to present the results of research on the attitude to smoking reflected in the folklore of modern smokers. Research material included data collected by the interview method in 2017-2019 in Bydgoszcz and nearby cities.

Thematic scope of the results presented in this article has been narrowed down to smokers' knowledge (currently or in the past) of small verbal forms (sayings, prohibitions, jokes) regarding cancer, superstitions, prophecies and electronic cigarettes. There were identified smokers' defense strategies against cancer threats, including humor, perversity, idealization.

Key words: smokers' folklore; prohibitions; jokes; defense strategies. 